\title{
Vaktaalrubriek
}

\section{Forum vir nuwe Afrikaanse chemieterminologie}

Saam met die snel groeiende wetenskaplike kennis, asook tegnologiese ontwikkelings oor 'n wye gebied, ontstaan ' $n$ behoefte aan nuwe terminologie en vaktaal. Nuwe terme word voortdurend gevorm (meestal in Engels), wat onmiddellik die behoefte aan vertalings in ander tale soos Afrikaans laat ontstaan. Terminologiegebruikers ontwikkel dan (dikwels in isolasie) terme in hul eie taal, sonder dat die aanvaarbaarheid daarvan vir die wyer taalgemeenskap getoets word. Erger nog, wetenskaplikes elders begin soms 'n heel ander term vir dieselfde begrip gebruik, wat onnodige verwarring veroorsaak wanneer normering en formele opname in die tegniese spreektaal ter sprake kom.

$\mathrm{Na}$ aanleiding van verskeie navrae in bogenoemde verband, het die Bestuur van die Afdeling Chemiese Wetenskappe van die Suid-Afrikaanse Akademie vir Wetenskap en Kuns besluit om 'n forum te skep waar navrae en voorstelle met betrekking tot nuwe chemieverwante terminologie byeengebring kan word. Dit sal d.m.v. die Vaktaalrubriek in hierdie Tydskrif gedoen word. Die gedagte is dat enigiemand met óf ' $n$ nuutgeskepte term óf ' $n$ behoefte aan 'n Afrikaanse vertaling van 'n nuwe Engelse term óf 'n navraag t.o.v. die aanvaarbaarheid van nuwe terminologie, dit aan die Afdeling Chemiese Wetenskappe sal verskaf. Daar sal dit deur'n subkomitee (wat onder andere dr. D.F. Louw, redakteur van die Nuwe Chemiewoordeboek insluit) bespreek word. Daarna sal dit aan die Nasionale Terminologiediens voorgelê word om oor die taalkundige aanvaarbaarheid en korrek theid te oordeel. Indien daar eenstemmigheid oor die wetenskaplike en taalkundige korrektheid van 'n nuwe term bestaan, sal dit voorlopig in die Nasionale Termbank opgeneem word.

Lesers en terminologiegebruikers sal deur middel van hierdie rubriek op hoogte gehou word van vordering in die verband. Terme waarvoor aanvaarbare Afrikaanse ekwivalente benodig word, of waaroor daar nie eenstemmigheid bestaan nie, sal ook vir lesers se insette voorgelê word. Terme wat vir algemene gebruik aanbeveel word, sal ook verskaf word.

Alle belangstellendes word hiermee uitgenooi om vrae en voorstelle oor nuwe Afrikaanse chemieterminologie voor te lê. Die klem met die aksie sal nie op 'n formele hersiening van die Nuwe Chemiewoordeboek val nie, maar eerder op nuwer terme wat onlangs op die toneel verskyn het. Nogtans kan die geleentheid ook benut word om leemtes in die woordeboek aan te vul. Die wenslike resultaat van so 'n program is dat die Nasionale Termbank gedurig opgedateer sal word wat nuwe chemieterminologie in Afrikaans betref.

Navrae en voorstelle kan gerig word aan:

Die Voorsitter

Afdeling Chemiese Wetenskappe

SA Akademie vir Wetenskap en Kuns

Posbus 538

PRETORIA

0001

Tel. (012) 328-5082

Faks. (012) 328-5091 